Discussion Paper No. 866

\author{
THE JONESES IN JAPAN: \\ INCOME COMPARISONS \\ AND FINANCIAL SATISFACTION \\ Andrew Clark \\ Claudia Senik \\ Katsunori Yamada
}

March 2013

The Institute of Social and Economic Research Osaka University

6-1 Mihogaoka, Ibaraki, Osaka 567-0047, Japan 


\title{
The Joneses in Japan: Income Comparisons and Financial Satisfaction*
}

\author{
Andrew E. Clark ${ }^{\dagger}$ (Paris School of Economics - CNRS) \\ Claudia Senik ${ }^{\ddagger}$ (Paris School of Economics and University Paris-Sorbonne) \\ Katsunori Yamada ${ }^{\S}$ (Institute of Social and Economic Research, Osaka University)
}

March 2013

\begin{abstract}
This paper uses Japanese data which includes measures of self-declared satisfaction, reference-group income, and the direction and intensity of income comparisons. Relative to Europeans, the Japanese compare more to friends and less to colleagues, and compare their incomes more. The relationship between satisfaction and others' income is negative, and more negative for those who report greater income comparison intensity. A self-reported measure of others' income does better than cell-mean income in explaining satisfaction, and would arguably make a useful addition to many existing surveys.
\end{abstract}

Keywords: Income Comparisons, Reference-Group Income, Reference Groups, Satisfaction.

JEL codes: D31, D63, I3, J31.

* Financial support from CEPREMAP, the Global COE program of Osaka University and the Grants-in-Aid for Scientific Research, the Japan Society for Promotion of Science, is greatly appreciated.

† PSE, 48 Boulevard Jourdan, 75014 Paris, France. Tel.: +33-1-43-13-63-29. E-mail: Andrew.Clark@ens.fr.

† PSE, 48 Boulevard Jourdan, 75014 Paris, France. Tel.: +33-1-43-13-63-12. E-mail: senik@pse.ens.fr.

$\S$ ISER, Osaka University, Mihogaoka 6-1, Ibaraki 567-0047, Japan. Tel. +81-6-68798566. E-mail: kyamada@iser.osaka-u.ac.jp. 


\title{
The Joneses in Japan: Income Comparisons and Financial Satisfaction
}

\author{
Andrew E. Clark, Claudia Senik and Katsunori Yamada
}

\section{Introduction}

Work on subjective well-being and income comparisons in economics has increased exponentially since the first labour-market based contributions of Cappelli and Sherer (1988), Clark and Oswald (1996) and Hamermesh (1977). While the broad idea that relative standing matters is now arguably accepted by many, it is still pretty much open season on the key questions of "How much" and "To whom".

We here contribute to this research area by using a novel Japanese dataset in which both the intensity and direction of income comparisons are measured. In terms of the latter, Japanese respondents compare mostly to their friends, followed by their colleagues. Regarding comparison intensity, we suggest that the Japanese are more comparison conscious than are Europeans.

We could establish the relationship between these two relatively unusual measures and individual satisfaction, as in Clark and Senik (2010). We instead here show that these two simple measures substantially mediate the effect of self-declared reference-group income. Those who say that they compare more indeed suffer more as others' income rises. Also, our self-reported measure of what "others like you earn" is far more salient for those who compare to colleagues than for those who compare to family or friends, say.

Last, we compare our self-reported measure of what others earn to researcherconstructed cell-mean measures of reference-group income, both from within the same internet data and matched in from external sources. While some of the researcherconstructed variables attract the right-signed coefficients in satisfaction regressions, overall the fit from the cell-mean data is far worse than that from regressions using the values from a simple question on others' earnings. This suggests that such a question may be a useful addition to survey questionnaires. 
The remainder of the paper is organized as follows. Section 2 describes the Japanese dataset which we use here, and Section 3 covers in particular the well-being and income comparison questions (where the latter are still very much a novelty in social science). Section 4 then presents our main results regarding satisfaction and income comparisons in Japan. Last, Section 5 concludes.

\section{Data}

\section{The internet survey}

Our data set is taken from an original web-based survey conducted in February $2010 .^{1}$ This survey was carried out by a Japanese consumer monitoring company, Nikkei Research Inc. under the direction of one of the authors. As part of the Nihon Keizai Shimbun Group (NIKKEI), this company is considered to be trustworthy and neutral, which makes it a suitable choice for data collection for academic research. To ensure the reliability of its research data, the subjects who register for consumer monitoring are subject to monthly screenings so that individual information remains up to date and double registrations are avoided.

The incentives for respondent participation in this particular project were provided by cash vouchers. ${ }^{2}$ The invitation email stated that the incentive would be paid on a lottery basis: 800 winners among those who completed the survey would receive 500 JPY per person. Subjects were ensured anonymity. Those who wished to participate were instructed to follow the link in the email which directed them to our stand-alone survey website. The survey was open for one week (February $18^{\text {th }}-25^{\text {th }} 2010$ ), and 14,370 subjects completed the survey. This approach reduces the bias inherent in one-day

\footnotetext{
${ }^{1}$ The recent use of the Internet to carry out social surveys is becoming increasingly widespread. Recent work using web-based surveys includes Viscusi et al. (2008), Ida and Goto (2009), Olsen (2009) and Bech et al. (2011).

${ }^{2}$ We used cash vouchers rather than point vouchers that can be redeemed against specific goods. The latter is considered to lead to potential bias, as particular respondent types (those interested in the good for which the points are destined) are more likely to respond to the survey. If these characteristics are not orthogonal to the right-hand side variables under consideration (here, comparison effects), the estimated coefficients will be biased. Our use of cash incentives avoids this problem.
} 
research, adopted by many other research companies for cost reasons. In one-day research, subjects are chosen on a first-come first-served basis, leading to potential bias from a potentially non-representative sample.

Nikkei Research, Inc. and the researchers commissioning the survey agreed on at least 10,000 survey respondents. Considering the response rates in seven similar academic choice-experiment surveys run by the same company in 2008 and 2009, invitation emails for this survey were sent to 60,482 subjects (out of over 160,000 registered in the Nikkei Database). ${ }^{3}$ The subjects, aged between 20 and 65, were chosen via stratified random sampling, so that the sample age profile mirrored Japanese census statistics. We could not match by education, as subjects do not have to declare this information when they register. The email specified that the survey was being carried out for research purposes and followed the disclosure requirements for research involving human beings provided with incentives as set forth by the ethics committee.

The survey consisted of three parts. The first collected information on satisfaction, which is our key dependent variable in this paper, and the second posed the hypothetical-choice questions over own and others' income which were analysed in Yamada and Sato (2010). The final section then consisted of questions about individual demographic characteristics, including age, sex, education, job, marital status, type of housing, residential area, and annual pre-tax personal income in 2009.

Table 1 compares the characteristics of our analysis sample, the construction of which is described below, to the overall statistics in the Japanese population. Columns (1) and (2) refer to men and women respectively in our analysis sample. Column (3) then presents descriptive statistics from the whole Nikkei Database, while the last column shows the figures for men and women in national Census statistics.

Table 1 shows that the stratified random sampling worked, in that the age and gender structure of our sample is similar to that in national statistics. Women account for something over 50 percent of both our sample and national statistics. There is however considerable under-representation of women who are divorced, separated or widowed.

\footnotetext{
${ }^{3}$ Broadband Internet access is pervasive in Japan.
} 
This difference from national statistics comes about because the latter include everyone aged over 15. As the average length of life for Japanese women is around 87 (with that of men being around 78), women tend to be widowed towards the end of their lives, which is reflected in the rate of female divorce/separation/widowhood in national statistics. However, as our sample only includes those who are aged up to 65, the rates of divorce/separation/widowhood for both men and women are lower than those in national statistics.

Only one percent of our male sample has their highest completed level of education as middle school, with 18 percent completing high school, 10 percent having some college, and the remaining 70 percent of the sample holding college or graduate degrees. The same high levels of education are found in the female sample. There is thus an obvious over-sampling of the better-educated here, likely reflecting a digital divide in terms of internet access or use. Analogously, we see from Table 1 an under-sampling of students and the unemployed, although for these two groups the difference from Census statistics is less severe. The cause of this gap is less clear, although there could again be a digital divide by labour-force status. Last, in terms of residential area there is clear oversampling from the Kanto region, which includes Tokyo, and to a lesser extent from the Kansai region, which contains Osaka. It could be argued that internet access is easier in urban areas.

Our sample is thus not entirely representative with respect to education and residential area. It is not clear how this might bias any relative utility effect. Higher education may cause individuals to become more altruistic, as argued in Johansson-Stenman et al. (2002). At the same time, education is positively correlated with earnings, which in turn may affect attitudes towards others. With respect to the residential area, Japanese urban dwellers are sometimes said to have become rather indifferent to their neighbours, so that social comparisons may be less salient for this group. On the other hand, they may well encounter others much more often, leading to feelings of rivalry. The European evidence in Clark and Senik (2010) showed that those with Internet access, city 
dwellers, and the more educated were more comparison-conscious. As such, our sample dataset may well capture the upper bound of comparison intensity. ${ }^{4}$

\section{Construction of the analysis sample}

The average time taken to complete the survey, including the hypothetical questions on preferences over combinations of own and others' income, was just over 9 minutes, with a median value of just over 6 minutes. ${ }^{5}$ We discard information from subjects with a completion time of under four minutes (968), following feedback from a withincompany pilot test supplied by NIKKEI. In the context of weeding out spurious responses, we also pay attention to the answer patterns supplied to the hypotheticalchoice questions. One easy way for subjects to finish the survey quickly is by providing the same answers to all of these choice questions, which are arguably the most difficult part of the survey. We therefore drop individuals who gave the same number for all five of the consecutive questions in the choice tasks $(2,218)$. This reduces the original sample to 10,988 respondents.

We also drop observations with missing values for any of the variables used in the happiness regressions below (219), and the one observation reporting retirement before the age of 55. Finally, we trim the top of the income distribution, by dropping the 565 individuals who reported a personal annual pre-tax income in 2009 of over twelve million Japanese Yen. ${ }^{6}$ To see whether this trimmed group reflected sample selection, we compare the dropped and retained groups along a number of different dimensions including age, education, marital status, and residential area. No significant differences were found, suggesting some potential mis-reporting of high incomes. Our final analysis sample covers 10,203 respondents. We thus lose about 30 percent of the initial sample. It is worth noting, however, that all of our main results listed below are qualitatively similar in the overall and analysis samples.

\footnotetext{
${ }^{4}$ See Johansson-Stenman et al. (2002) for a discussion of other potential biases, including the purchase of moral satisfaction (Kahneman and Knetsch, 1992) associated with hypothetical-choice experiments referring to relative utility.

${ }^{5}$ Observations with no recorded elapsed time (90) or an elapsed time of over one hour (106) are excluded from the analysis sample.

${ }^{6}$ This cut-off point, JPY 12 million, is three standard deviations over the mean value of personal pre-tax annual income. At the March 2009 exchange rate, 12 million Japanese Yen is around 130,000 US dollars.
} 


\section{Happiness, income comparisons and reference income}

The happiness and comparison questions

The first question in this category asked respondents about their satisfaction with income. The answers were on a five-point scale, with 1 corresponding to "least satisfied" and 5 "most satisfied". The second question covered social comparisons and was phrased as "How much are you concerned, anxious or envious about other people's incomes?" Respondents chose from five response options, where 1 corresponded to "Not at all" and 5 to "Very". Respondents were then asked about their reference group to whose income they compare. They chose one category from (i) family, (ii) neighbours, (iii) friends, (iv) work colleagues, (v) do not care about comparisons, and (vi) others. These last two questions therefore provide information on both "Who compares to whom?" and "How much?" These two questions were analysed in the European context by Clark and Senik (2010), where they were denoted the direction and intensity components of income comparisons.

We first consider the direction of income comparisons. Table 2 shows the distribution of the income reference groups that were indicated by respondents. The reference group chosen the most often is friends (42\%), followed by work colleagues (20\%); around a quarter of the sample say that they do not make such income comparisons. It is of interest to compare these rankings to those from Wave 3 of the European Social Survey in Clark and Senik (2010). In both Europe and Japan, friends and work colleagues are the two most important reference groups. However, their relative importance is completely inverted. While in Japan, twice as many respondents indicate friends as the reference group, as compared to work colleagues, the European results in Clark and Senik (2010) have work colleagues (36\%) being twice as important as friends (15\%). In both countries, the other named income reference groups are of only marginal importance. Individuals can also indicate that they do not compare their income to others, in the sense that they do not have an income comparison group. In Japan this figure (25\%) is notably lower than that in Europe (36\%). To this extent, the Japanese 
may be considered to be more comparison-conscious (at least in the realm of income) than are Europeans.

Table 3 shows the cross-tabulation of the direction and intensity of social comparisons. Those who do not think that comparisons are at all important tend not to declare comparison groups, which is only natural. Respondents who say that they compare to family, neighbours or work colleagues tend to say that comparisons are more important than do those whose income reference group is friends. The chi-squared statistic for this table (with 20 degrees of freedom) is over 3000 and is significant at all conventional levels (the critical value at the $0.1 \%$ level being 45.3 ): the direction and intensity of social comparisons are indeed correlated.

The last column of Table 3 shows the overall distribution of the intensity of income comparisons in Japan. While 30 percent of Japanese respondents give an answer of one or two on the one to five scale, over 40 percent give an answer of 4 or 5 , indicating that they find it important to compare their incomes. It is not easy to compare these figures to their European counterparts in Clark and Senik (2010), as comparison intensity in the European Social Survey is measured on a 0 to 6 scale rather. We can however compare the percentage saying that income comparisons are "not at all important" (the lowest value on the scale). This is only six percent in Japan, but 25 per cent in Europe (despite the scale there being wider). This reinforces our conclusion above that the Japanese may be more comparison-conscious than are Europeans.

\section{Own income}

In the survey respondents report their own annual pretax income using a list of 11 categories, where category 1 refers to an annual figure of below 2 million Yen and category 11 corresponds to an annual income of over 50 million Yen. Income is calculated as the mid-point of each of the nine intermediate categories, with ad hoc values of 1.5 and 55 million Yen being assigned to the two extreme categories. Over the whole internet sample, this produces average annual pretax income figures of 5.69 and 2.93 million Yen for men and women respectively. In the analysis sample all individuals with income of over 12 million Yen are dropped. Average own pretax annual income for men is then 4.9 million Yen (around 53000 US Dollars) in Table 1. 
The figure for women is notably lower at 2.7 million Yen. All of the income variables are entered in log form in the regression analysis.

We also have available three different measures of the income to which individuals may compare their own income. One of these is a self-reported measure of the income that "people like you" earn; the other two are constructed as cell means, one from with in the database and the other from an external data source.

\section{Self-reported reference income}

The first measure of comparison income is provided by the respondents themselves. The Japanese internet survey asks respondents directly about reference incomes: “About how much do you suppose was the average personal income (before taxes) in 2009, for people of the same age, sex, and education as you?” The answers are given on the same 11-point scale used for own income above. As such we can compare the coefficient on reference income in a happiness regression directly to that on own pre-tax income, as both are measured in the same units. Equally, it is arguably of use to have information on what individuals believe others earn, as it is this figure which is likely important for their feelings of deprivation or satisfaction. The disadvantage of this question is that it captures the reference income only of one particular group defined in a Leyden-group fashion as a cell mean. We do not know if this group is always the most salient for the kind of income comparisons that individuals carry out. We argue that this measure of self-reported reference income will still capture some part of the effect of income comparisons, as it is likely correlated with the real income to which the individual compares.

The figures in Table 1 show that both men and women believe that they earn less than do comparable others. Men think that others with the same productive characteristics earn on average around $20 \%$ more than they do, while the comparable figure for women is a remarkable $64 \%$.

Cell means - internal

Our second measure of reference group income is given by the cell mean from within the internet survey. In order to ensure the greatest compatibility with the other two 
measures here, this will be calculated using cells defined by age, education, gender and labour-force status (as described below). The average cell-mean internal income is the same as average own income within the survey, by construction (see Table 1).

Cell means - external sources

Our last measure of reference group income comes from an external source. This corresponds to the income of individuals in a number of different labour-force statuses: (i) employed in the private sector, (ii) in professional jobs, (iii) civil servants, (iv) temporary workers, (v) other public sector (but not civil servants), (vi) unemployed and receiving benefits, and (vii) self-employed. Income information for these groups are provided by the Basic Survey on Wage Structure (BSWS) released by the Japanese Ministry of Health, Labour and Welfare. ${ }^{7}$

For those in situations (i) and (iii), we construct cell average income levels by sex, and age and education categories. For individuals in (ii) we appeal to information on the income of doctors and chartered accountants. The cell averages for this group are by age and gender, but not by education (as that varies only little in this professional group). For group (v), we have no direct information. These positions are public sector but inferior to those in group (iii). We thus assume that the income of those in group (v) is proportional to that in group (iii). For those in temporary jobs, we have information on the average number of working days per month, working hours per day, and wage per hour by age and gender. We infer annual income levels from this information. For the unemployed, we have income information from unemployment insurance. We assume for simplicity that the unemployed have no other sources of income. Last, we use information on the before-tax income by age of the self-employed.

Figure 1 shows that average cell income from the BSWS is around $15-20 \%$ higher than that reported within the dataset. This discrepancy reflects the fact that housewives are included as one of the labour-force categories within the dataset, whereas we have no such information in the external dataset. As housewives report lower than average annual income, the internet survey figure is below that in the BSWS.

\footnotetext{
${ }^{7}$ The data can be obtained from: http://www.mhlw.go.jp/english/database/dbl/.
} 


\section{Satisfaction and Income Comparisons in Japan}

Our goal here is not just to catalogue the direction and intensity of income comparisons in Japan, but also to see how these relate to income satisfaction. To do so we are going to marry two disparate strands of the literature. The first considers how comparison income levels affect various measures of subjective well-being. Comparison income in this literature is most often considered here as either a Leyden-type cell mean or a predicted value from a Mincerian earnings equation (measuring "what other people like me earn"). The cell mean can refer to the whole country (Easterlin, 1974, and Stevenson and Wolfers 2008), a more disaggregated geographical area (Clark et al. 2009a, Ferreri-Carbonell, 2005, and Luttmer, 2005), or colleagues in the same workplace (Cappelli and Sherer, 1988, Brown et al., 2008, and Clark et al. 2009b). The predicted value from an earnings equation, as in Clark and Oswald (1996), is similar in nature, calculating expected mean earnings conditional on all of the control variables in the earnings equation.

Controlling for own income, others' income is typically negatively correlated with individual well-being (see the survey in Clark et al., 2008), although others' incomes may sometimes serve to provide information about the individual's own likely future income (Senik, 2004).

The second, much smaller, strand of research has considered the different reference groups to which individuals compare and/or the intensity of comparisons. ${ }^{8}$ As well as the work in Clark and Senik (2010) based on data from the European Social Survey, Senik (2009) provides direct evidence from 25 post-Transition countries (LITS) that comparisons affect subjective well-being and evaluates the relative importance of the different benchmarks. Internal comparisons to one's own past living standard are the most important, but local comparisons (to parents, former colleagues or high-school friends) also matter, especially upward comparisons.

\footnotetext{
${ }^{8}$ An associated, but more specific question, concerns the direction of comparisons of immigrants, as in Stark and Taylor (1991): do they compare to the home or host country? In Gelatt (2013) immigrants' affective well-being is more affected by comparisons to others in the United States than to those in the home country.
} 
Somewhat analogously, in Sági (2011) respondents in Ukraine, Poland, Hungary and Georgia were asked to name three groups to which they compare their own standard of living, and how they thought the standard of living in these three groups compared to that in the respondent's own country. The potential reference groups were neighborhood, friends, earlier standard of living, wealthy people in respondent country, average of the country, average of the former socialist countries, and average of the West European countries. Respondents tended to compare upwards, in using reference groups that were in a better financial situation. The most popular reference groups were own earlier living standards, current country average, and current neighbourhood average. In a logistic regression, comparing to the local neighbourhood reduces the individual's satisfaction with standard of living, while comparing to former communist countries raises satisfaction.

In research on Asia, Knight et al. (2009) used survey data from Chinese households to show that, when asked explicitly to whom they compare themselves, $68 \%$ of survey respondents report that their main comparison group consists of individuals in their own village.

The paper the most closely-related to our own is Mayraz et al. (2009), who use a small sample from the 2008 pre-test module of the Socio-Economic Panel Study (SOEP). They ask both about the intensity of their income comparison to various reference groups (on a 1-7 scale, from "completely unimportant" to "extremely important"), and then how their income compares to that of these groups on a 1-5 scale (from "much lower" to "much higher"). Half of respondents say that income comparisons are completely unimportant: this is most true for comparisons to neighbours, and least true for comparisons to colleagues. Life satisfaction is shown to fall with the intensity of comparisons, as in Clark and Senik (2010).

We are here in the rather advantageous position of having not only information on wellbeing and comparison intensity and direction, but also a number of different measures of individual comparison income (both self-reported and constructed as a cell mean, either within the dataset or from an external source). As such, we are arguably able to put all the various pieces of information in the existing literature above together. We 
thus ask whether intensity and direction moderate the effect of comparison income on satisfaction.

The first question is a fairly simple one: the more I care about comparisons, the greater should be the effect of comparison income on my satisfaction. The second question asks whether the correlation between comparison income and satisfaction is moderated by the group to which I compare. As the measures of reference group income above are constructed by age, sex and education, they may be thought (for example) to provide a closer fit to the income profile of the individual's work colleagues and friends rather than their neighbours or family.

\section{Satisfaction and Comparison Intensity}

The relationship between the intensity of income comparisons and reference group income is explored in Table 4. The estimation method here is OLS, although similar results pertain if we instead use an ordered probit. The first column of this table shows the results from a relatively standard regression of income satisfaction on own income, reference group income (here self-reported) and a number of demographic controls. All of the income variables are entered in logarithms in the regressions. The results reveal a positive relationship between income satisfaction and own income, but a negative relationship with reference-group income. The size of the two estimated coefficients suggests that the satisfaction effect of a ten percent (say) rise in income is about half as large again when only I receive it, as opposed to when it is received by both myself and the members of my reference group. ${ }^{9}$

Column 2 of Table 4 adds the index of comparison intensity to the specification. This is here treated as a cardinal variable, taking on the values of one to five. As in Clark and Senik (2010), the more the individual compares to others the less satisfied they are. ${ }^{10}$ Last, in column 3 we test whether comparison intensity tempers the effect of reference-

\footnotetext{
${ }^{9}$ It is of interest to run this regression separately for men and women. The coefficient on own income is larger for men by a factor of three, and that on comparison income is larger by a factor of 8 . The $\mathrm{R}^{2}$ for men is twice as high as that for women. As such, income matters more for men, and they are more comparison-sensitive.

${ }^{10}$ Although we cannot of course rule out reverse causality in this cross-section data, with lower levels of subjective well-being leading individuals to become more status-conscious.
} 
group income. We find that this is indeed the case. In this specification with an interaction, both of the main effects (comparison income and intensity) attract insignificant coefficients, but the interaction between them is negative and significant. To illustrate the impact of this interaction, consider a rise in reference group income of one log point. If I report the lowest comparison intensity of one, this rise is estimated to reduce my satisfaction by 0.1 points. However, if I report the maximum comparison intensity of five, this one log point rise in others' income reduces my income satisfaction by just over half of a point (which is a sizeable movement on a one to five satisfaction scale). Hence, the brunt of the effect of income comparisons is indeed borne by those who declare that this is more important for them.

The estimated coefficients on the other right-hand side variables are reassuringly similar to those that are found in existing work (which has mostly used data from Western countries). Women report higher satisfaction scores than do men (Nolen-Hoeksema and Rusting, 1999), while satisfaction is U-shaped in age, with a minimum at about age 46 (Clark et al., 1996). Education in Japan is strongly positively correlated with income satisfaction, even controlling for the level of income. This perhaps runs a little contrary to existing work, which has often struggled to find a clear correlation between wellbeing and education (see Clark et al., 2012). Last, marriage is found to be positively correlated with satisfaction in our cross-section data (although a reverse causality reading is of course possible here: see Stutzer and Frey, 2006).

\section{Satisfaction and Comparison Direction}

Table 5 then turns to the direction of income comparisons. We here re-estimate satisfaction with income using the specification from the first column of Table 4 separately for each of the different possible reference groups to which the individual can compare. Reference-group income, as was the case in Table 4, is self-reported (as the individual's guess of the average income of individuals of the same age, sex, and education as themselves).

The first column of Table 5 shows the estimates over the whole sample, as in Table 4, where both own and reference group income are significant, with the latter being about $40 \%$ the size of the former. The remainder of the table splits the sample up according to 
the direction of comparisons. It can be seen that reference group income is associated with significantly lower income satisfaction for those who compare to colleagues or to "others", as well (but with a coefficient only half as large) as for those who compare to neighbours or friends. Reference-group income is insignificant for those who compare to family, or who say they don't compare. As noted above, this self-report measure of others' income does therefore seem to provide a meaningful measure for a number of reference groups, and especially work colleagues. Own income is positive and significant in all of the different regressions in Table 5.

The estimated relative importance of own income and reference-group income in these regressions is strikingly similar to that found in the hypothetical-choice experiments using the same dataset in Yamada and Sato (2010). For example, in the whole sample in column 1 of Table 5, the ratio of the effect of reference-group income to own income is about -0.39 . The analogous figure from the analysis of the hypothetical-choice questions for the same individuals in Table 4 of Yamada and Sato (2010) is -0.46 . For the other columns of Table 5, very similar trade-offs are also found for those who compare to their neighbours, friends or colleagues. ${ }^{11}$

\section{Which Measure of Comparison Income Matters Most?}

The regression results discussed so far have used self-reported reference income levels. Table 6 then considers the relationship between satisfaction and comparison income, but using a cell-mean measure of reference group income from within the same internet survey, as described in Section 3 above. ${ }^{12}$ All of the regressions in Table 6 allow for standard errors that are clustered at the level of the cells used to construct the average reference income, for reasons that are set out in Moulton (1990). The specification here is the same as that which appears in the first column of Table 4.

\footnotetext{
${ }^{11}$ The empirical analysis of subjective measures using mixed methods is rare. One exception is Clark et al. (2010), who consider the role of income comparisons in determining the level of effort exerted by workers, using both experimental and large-scale international survey data.

12 Oshio et al. (2011) use a cell-mean (gender $x$ age $x$ education) approach to analyse life satisfaction in three Asian countries, among which Japan. Reference-group income is negatively correlated with satisfaction in all three countries.
} 
The results in Table 6 show that this new measure of comparison income attracts a wide variety of estimated coefficients, depending sharply on the cells that are used to construct it. In general, age seems to be a salient component of reference income: all of the point estimates on reference income from cells including age are negative, while all of those from cells which do not use age are positive. However, many of these negative coefficients are insignificant, and only that from the reference group defined by region and age is negative and significant. Hence the cell-mean measure of reference-group income seems to behave significantly worse than the previous self-reported measure, in terms of picking up any comparison-income effects. ${ }^{13}$

We can also split the sample up by direction of comparison, as in Table 5. The results (available on request) show that this internal cell mean (from the same dataset) continues to perform poorly. In particular, across the six comparison groups the estimated coefficient on comparison income is never negative and significant, and the point estimate is actually positive for three groups.

One way of reading this result is that the data from the internet survey does not actually provide a very good measure of the income in the different cells. We therefore turn to the external cell-mean income information from the BSWS. Table 7 reruns all of the regressions in Table 5. While the signs of the estimated coefficients on comparison income agree with those in Table 5 in five out of the seven regressions, only two of the relevant coefficients in Table 7 are significant, and then only at the ten percent level. Overall, it then seems that self-reported levels of what others like me earn are far more salient in providing comparison-income information than are a variety of both internal and external cell-mean measures.

\footnotetext{
${ }^{13}$ De la Garza et al. (2010) test for income comparisons among Japanese union workers using a variety of reference-income variables. They also find that self-reported reference-group information (the income of people like you) provides the best fit to the data. They also propose a simple IV strategy for happiness regressions when self-reported reference income information is not available, which is the main contribution of their paper. They do not have information on the direction of comparisons.
} 


\section{Conclusions}

This paper has used relatively large-scale internet survey data from Japan to lift part of the veil regarding the process of income comparisons. In contrast to the vast majority of empirical work in the area of subjective well-being, we are able to measure both the direction (to whom?) and intensity (how much?) dimensions of income comparisons. Respondents compare first to friends and then to work colleagues, whereas this order is inverted in Europe. In addition, the intensity of income comparisons is higher in Japan than in Europe.

Beyond documenting the existence of income comparisons, we also show that they matter for subjective well-being. Satisfaction with standard of living rises with own income, and falls with the income of the reference group. This latter correlation is mediated by both the intensity and the direction of income comparisons. The relationship between satisfaction and others' income is indeed more negative for those who state that they compare their incomes more; in addition, it is stronger for those who compare their incomes to those of their colleagues than for those who compare to family or friends, say.

Our final contribution concerns the measure of the relevant reference-group income. It is common in non-experimental work to calculate "others' income" as some conditional or unconditional cell-mean, with the cells being defined by neighbourhood, workplace or demographic type. We here show that two such cell-mean measures (one from within the dataset, the other matched in from external sources) fit the well-being data worse than does a simple self-reported measure of what relevant others earn.

There are two ways of reading this result. Either simple questions on others' earnings are better able to capture the actual reference group to which our respondents compare, or it is not what others actually do earn that matters, but rather what individuals believe they earn.

In our survey, the "relevant others" were defined by age, sex, and education. While we have shown that this question does indeed capture some useful information, there is no 
reason why the same question could not be asked about the neighbourhood or the workplace. In general, asking questions about self-reported comparison income would seem a simple useful addition to current surveys, in the same way that the addition of subjective questions to many has helped contribute to the current outpouring of research across the social sciences on individual and societal well-being. 


\section{Appendix. Questionnaire}

Satisfaction and Income-Comparison Questions:

1. How satisfied are you with the amount of your current income?

1: Extremely dissatisfied.

2: Dissatisfied

3: Neither dissatisfied nor satisfied

4: Satisfied

5: Extremely satisfied

2. How much are you concerned, anxious or envious about other people's income?
1: Not at all
2: Not much
3: Neither yes nor no
4: Fairly much
5: Very much

3. When you compare the amount of your income with that of someone else, which of the following best describes that person?
1: Family
2: Neighbour
3: Friend
4: Colleague
5: Don’t compare
6: Others 
Demographic Variable Questions:

1) What is your age in years?

2) What is your sex?

3) What is your highest educational qualification?

4) What is your occupation?

5) What is your marital status?

6) What best describes your current residence? (Type of dwelling, for example a house that you own)

7) Where do you live? (Which prefecture in Japan)

8) What was your approximate personal income (before taxes) in 2009? Please also include pension income, remittances, and so on.

9) About how much do you suppose was the average personal income (before taxes) in 2009, for people of the same age, sex, and education level as you? 


\section{References}

Bech, M., T. Kjaer and J. Lauridsen (2011), "Does the number of choice sets matter? Results from a web survey applying a discrete choice experiment," Health Economics, 20, 273-286.

Brown, G. D. A., J. Gardner, A. J. Oswald and J. Qian (2008), "Does Wage Rank Affect Employees’ Well-being?,” Industrial Relations, 47, 355-389.

Cappelli, P. and P. D. Sherer (1988), "Satisfaction, Market Wages, \& Labor Relations: An Airline Study,” Industrial Relations, 27, 56-73.

Clark, A.E., Frijters, P., and Shields, M. (2008). "Relative Income, Happiness and Utility: An Explanation for the Easterlin Paradox and Other Puzzles". Journal of Economic Literature, 46, 95-144.

Clark, A. E., N. Kristensen and N. Westergard-Nielsen (2009a), "Economic Satisfaction and Income Rank in Small Neighbourhoods," Journal of the European Economic Association, 7, 519-527.

Clark, A. E., N. Kristensen and N. Westergard-Nielsen (2009b), "Job Satisfaction and Co-worker Wages: Status or Signal?,” Economic Journal, 119, 430-447.

Clark, A.E., Layard, R., and Senik, C. (2012). "The causes of happiness and misery”. In J. Helliwell, R. Layard, and J. Sachs (Eds.), World Happiness Report. New York: Columbia Earth Institute.

Clark, A.E., Masclet, D., and Villeval, M.-C. (2010). "Effort and Comparison Income”. Industrial and Labor Relations Review, 63, 407-426.

Clark, A. E. and A. J. Oswald (1996), "Satisfaction and comparison income," Journal of Public Economics, 61, 359-381.

Clark, A.E., Oswald, A.J., and Warr, P.B. (1996). "Is Job Satisfaction U-shaped in Age?” Journal of Occupational and Organizational Psychology, 69, 57-81.

Clark, A.E. and C. Senik (2010), "Who compares to whom? The anatomy of income comparisons in Europe,” Economic Journal, 120, 573-594.

de la Garza, A., G. Mastrobuoni, A. Sannabe and K. Yamada (2010), "The Relative Utility Hypothesis With and Without Self-reported Reference Wages," ISER Discussion Paper 795, Osaka University.

Easterlin, R. (1974). "Does Economic Growth Improve the Human Lot? ” In P.A. David and W.B. Melvin (Eds.), Nations and Households in Economic Growth. Palo Alto: Stanford University Press.

Ferrer-i-Carbonell, A. (2005). "Income and well-being: an empirical analysis of the comparison income effect”. Journal of Public Economics, 89, 997-1019. 
Fujita, F. (2008). "The Frequency of Social Comparison and Its Relation to Subjective Well-Being”. In M. Eid and R. Larsen (Eds.), The Science of Subjective Well-Being. New York and London: Guilford Press.

Gelatt, J. (2013). “Looking Down or Looking Up: Status and Subjective Well-Being among Asian and Latino Immigrants in the United States”. International Migration Review, forthcoming.

Hamermesh, D.S. (1977). “Economic Aspects of Job Satisfaction”. In O.C.Ashenfelter and W.E.Oates (Eds.), Essays in Labor Market Analysis. New York: John Wiley.

Ida, T. and R. Goto (2009), "Simultaneous Measurement of Time and Risk Preferences: Stated Preference Discrete Choice Modeling Analysis Depending on Smoking Behavior,” International Economic Review, 50, 1169-1182.

Johannsson-Stenman, O., Carlsson, F., and Daruvala, D. (2002). "Measuring Future Grandparents' Preferences for Equality and Relative Standing”. Economic Journal, 112, 362-383.

Kahneman, D. and J. L. Knetsch (1992). "Valuing public goods: The purchase of moral satisfaction” . Journal of Environmental Economics and Management, 22, $57-70$.

Knight, J., Song, L. and Gunatilaka, R. (2009). "Subjective Well-being and its Determinants in Rural China”. China Economic Review, 20, 635-649.

Luttmer, E. (2005). "Neighbors as Negatives: Relative Earnings and Well-Being”. Quarterly Journal of Economics, 120, 963-1002.

Mayraz, G., Wagner, G. and Schupp, J. (2009). "Life Satisfaction and Relative Income: Perceptions and Evidence”. IZA Discussion Paper 4390, Institute for the Study of Labor (IZA)

Moulton, B. (1990). “An Illustration of a Pitfall in Estimating the Effects of Aggregate Variables on Micro Units”. Review of Economics and Statistics, 72, 334-38.

Nolen-Hoeksema, S., and Rusting, C.L. (1999). "Gender differences in well-being”. In D. Kahneman, E. Diener, and N. Schwartz (Eds.), Well-being: The foundations of hedonic psychology. New York: Russell Sage Foundation.

Olsen, S. (2009), "Choosing Between Internet and Mail Survey Modes for Choice Experiment Surveys Considering Non-Market Goods,” Environmental \& Resource Economics, 44, 591-610.

Oshio, T., Nozaki, K., and Kobayashi, M. (2011). "Relative income and happiness in Asia: Evidence from nationwide surveys in China, Japan, and Korea”. Social Indicators Research, 104, 351-367.

Sági, M. (2011), "Determinants of Satisfaction with Living Standards in Transition Societies”, International Journal of Sociology, 41, 55-78. 
Senik, C. (2004). "When Information Dominates Comparison: A Panel Data Analysis Using Russian Subjective Data”. Journal of Public Economics, 88, 2099-2123.

Senik C. (2009), "Direct Evidence on Income Comparisons and their Welfare Effects", Journal of Economic Behavior and Organization, 72, 408-424.

Stark, O., and Taylor, J.E. (1991). "Migration Incentives, Migration Types: The Role of Relative Deprivation”. Economic Journal, 101, 1163-1178.

Stevenson, B., and Wolfers, J. (2008). "Economic Growth and Subjective Well-Being: Reassessing the Easterlin Paradox". Brookings Papers on Economic Activity, Spring, 1-102.

Stutzer, A., and Frey, B.S. (2006). “Does Marriage Make People Happy, Or Do Happy People Get Married?”. Journal of Socio-Economics, 35, 326-347.

Viscusi, W. K., J. Huber and J. Bell (2008), "Estimating discount rates for environmental quality from utility-based choice experiments," Journal of Risk and Uncertainty, 37, 199-220.

Yamada, K. and M. Sato (2010), "Another Avenue for Anatomy of Income Comparisons: Evidence from Hypothetical Choice Experiments," Journal of Economic Behavior and Organization, forthcoming. 


\section{Tables}

Table 1.Descriptive Statistics of the Regression Sample

\begin{tabular}{|c|c|c|c|c|c|}
\hline & \multicolumn{2}{|c|}{ (1) } & $(2)$ & \multicolumn{2}{|r|}{ (3) } \\
\hline & \multicolumn{2}{|c|}{$\begin{array}{c}\text { Our Survey } \\
\text { (analysis sample) }\end{array}$} & \multirow[t]{2}{*}{ NIKKEI } & \multicolumn{2}{|c|}{ National Data (b) } \\
\hline & Male & Female & & Male & Female \\
\hline Female [0.1] & \multicolumn{2}{|c|}{55.6} & \multirow[t]{2}{*}{56.6} & \multirow{2}{*}{\multicolumn{2}{|c|}{51.3}} \\
\hline \multicolumn{3}{|l|}{ Age category } & & & \\
\hline $20-29$ & 18.1 & 21.5 & 13.7 & 19.5 & 18.7 \\
\hline $30-39$ & 25.4 & 23.2 & 36.4 & 24.5 & 24.1 \\
\hline $40-49$ & 19.2 & 24.8 & 30.1 & 21.8 & 21.7 \\
\hline $50-59$ & 22.5 & 18.9 & 13.9 & 22.1 & 22.6 \\
\hline $60-65$ & 14.8 & 11.7 & 5.9 & 12.1 & 12.8 \\
\hline \multicolumn{6}{|l|}{ Education (a) } \\
\hline \multirow{4}{*}{$\begin{array}{l}\text { Middle school } \\
\text { High school } \\
\text { Some college } \\
\text { College }\end{array}$} & 0.9 & 0.9 & & 18.2 & 20.8 \\
\hline & 21.2 & 25.9 & & 41.6 & 43.4 \\
\hline & 11.1 & 32.1 & & 11.4 & 24.5 \\
\hline & 66.7 & 41.1 & & 28.3 & 10.7 \\
\hline \multicolumn{6}{|l|}{ Marital Status } \\
\hline \multirow{3}{*}{$\begin{array}{l}\text { Single } \\
\text { Married } \\
\text { Divorced/Separated/Widowed }\end{array}$} & 33.2 & 25.8 & \multirow{3}{*}{$\begin{array}{c}30.0 \\
60.7 \\
9.3\end{array}$} & \multirow{4}{*}{$\begin{array}{c}32.0 \\
61.8 \\
6.2\end{array}$} & \multirow{4}{*}{$\begin{array}{l}23.4 \\
57.6 \\
19.0\end{array}$} \\
\hline & 63.3 & 67.9 & & & \\
\hline & 3.5 & 6.3 & & & \\
\hline \multicolumn{3}{|l|}{ Region } & \multirow{18}{*}{$\begin{array}{c}4.0 \\
4.1 \\
46.9 \\
3.7 \\
9.5 \\
19.7 \\
3.8 \\
1.9 \\
6.4 \\
\text { N.A. } \\
\text { N.A. }\end{array}$} & & \\
\hline \multirow{2}{*}{$\begin{array}{l}\text { Hokkaido } \\
\text { Tohoku }\end{array}$} & \multicolumn{2}{|c|}{4.7} & & \multicolumn{2}{|r|}{4.3} \\
\hline & \multicolumn{2}{|c|}{4.4} & & \multicolumn{2}{|r|}{7.4} \\
\hline \multirow{2}{*}{$\begin{array}{l}\text { Kanto } \\
\text { Koshinetsu }\end{array}$} & \multicolumn{2}{|c|}{44.2} & & \multicolumn{2}{|c|}{32.9} \\
\hline & \multicolumn{2}{|c|}{4.2} & & & 6.7 \\
\hline Chubu & & & & & 11.9 \\
\hline Kansai & & & & & 16.3 \\
\hline Chugoku & & & & & 6.0 \\
\hline Shikoku & & & & & 3.1 \\
\hline Kyushu & & & & & 11.4 \\
\hline Student [0.1] & & 4 & & & 7.6 \\
\hline Unemployment & & 0 & & & 4.9 \\
\hline Income satisfaction & 2.22 & 2.27 & & & \\
\hline Annual income (Thousand Yen) & & & & & \\
\hline Own income in survey & 4902 & 2709 & & & \\
\hline Reference income in survey & 5993 & 4458 & & & \\
\hline $\begin{array}{l}\text { Income of Cell average } \\
\text { (age*gender*education*job) }\end{array}$ & 4902 & 2709 & & & \\
\hline $\begin{array}{l}\text { Income of cell average from External } \\
\text { source (age*gender*education*job) }\end{array}$ & 5555 & 3237 & & & \\
\hline
\end{tabular}

All figures are in percent for each category except for the annual personal pretax income variables.

(a) Those who are currently students are excluded from the figure.

(b) Demographic characteristics are from the Population Estimates by the Statistics Bureau (Sep. 2009). Education is from the Employment Status Survey (Table 3; 2007) by the Statistics Bureau. Marital Status is from the Population Statistics of Japan (Table 6.21; 2008) by National Institute of Population and Social Security Research. Region is from the Population Statistics of Japan (Table 9.5; 2008). and the unemployment rate is from the Labour Force Survey (Feb. 2010) by the Statistics Bureau. 
Table 2. The Direction of Self-Declared Income Comparisons

\begin{tabular}{|l|cccccc|}
\hline & Family & Neighbours & Friends & Colleagues & Don't compare & Others \\
\cline { 1 - 6 } Observations & 483 & 578 & 4279 & 2024 & 2592 & 247 \\
\cline { 1 - 5 } Percent & 4.7 & 5.7 & 41.9 & 19.8 & 25.4 & 2.4 \\
\hline
\end{tabular}

Table 3. Cross-Tabulation of the Direction and Intensity of Income Comparisons

\begin{tabular}{|lccccccc|}
\hline Comparisons & Family & Neighbours & Friends & Colleagues & $\begin{array}{c}\text { Don't } \\
\text { compare }\end{array}$ & Others & Total \\
& & & & & & & \\
Not at All & 3.0 & 0.5 & 13.2 & 8.0 & 74.3 & 0.9 & 100.0 \\
& 3.9 & 0.5 & 2.0 & 2.5 & 18.2 & 2.4 & 6.2 \\
Not Much & 4.1 & 2.8 & 24.9 & 15.2 & 51.7 & 1.3 & 100.0 \\
& 21.1 & 11.8 & 14.3 & 18.8 & 49.2 & 13.4 & 24.2 \\
Neither Yes nor No & 5.5 & 5.2 & 40.2 & 20.0 & 26.9 & 2.3 & 100.0 \\
& 33.8 & 27.0 & 28.0 & 29.5 & 30.9 & 27.5 & 29.2 \\
Fairly Much & 4.7 & 8.4 & 58.3 & 24.2 & 1.1 & 3.4 & 100.0 \\
& 35.2 & 52.8 & 49.5 & 43.5 & 1.5 & 49.4 & 35.7 \\
Very Much & 6.0 & 9.5 & 54.7 & 25.3 & 0.8 & 3.7 & 100.0 \\
& 6.0 & 8.0 & 6.2 & 6.0 & 0.2 & 7.3 & 4.7 \\
& 4.7 & 5.7 & 41.9 & 19.8 & 25.4 & 2.4 & 100.0 \\
Total & & & & & & & \\
\end{tabular}

Note: Figures in italics are row percentages. 
Table 4. OLS Estimates of Satisfaction with Income

\begin{tabular}{|c|c|c|c|}
\hline & (1) & (2) & (3) \\
\hline Dependent Variable & \multicolumn{3}{|c|}{ Satisfaction with income } \\
\hline Own income & $\begin{array}{c}0.360^{* * *} \\
(0.020)\end{array}$ & $\begin{array}{c}0.350^{* * *} \\
(0.020)\end{array}$ & $\begin{array}{c}0.351^{* * *} \\
(0.020)\end{array}$ \\
\hline Self-reported reference income & $\begin{array}{c}-0.134^{* * *} \\
(0.021)\end{array}$ & $\begin{array}{c}-0.127^{* * *} \\
(0.021)\end{array}$ & $\begin{array}{l}-0.028 \\
(0.051)\end{array}$ \\
\hline Comparison Intensity & & $\begin{array}{c}-0.482^{* * *} \\
(0.030)\end{array}$ & $\begin{array}{c}1.115 \\
(0.750)\end{array}$ \\
\hline Reference Income * Intensity & & & $\begin{array}{c}-0.104^{* *} \\
(0.049)\end{array}$ \\
\hline Female & $\begin{array}{c}0.228^{* * *} \\
(0.022)\end{array}$ & $\begin{array}{c}0.230^{* * *} \\
(0.022)\end{array}$ & $\begin{array}{c}0.229^{* * *} \\
(0.022)\end{array}$ \\
\hline Age & $\begin{array}{c}-0.057^{* * *} \\
(0.006)\end{array}$ & $\begin{array}{c}-0.059^{* * *} \\
(0.006)\end{array}$ & $\begin{array}{c}-0.058^{* * *} \\
(0.006)\end{array}$ \\
\hline Age squared/100 & $\begin{array}{c}0.062^{* * *} \\
(0.007)\end{array}$ & $\begin{array}{c}0.063^{* * *} \\
(0.007)\end{array}$ & $\begin{array}{c}0.063^{* * *} \\
(0.007)\end{array}$ \\
\hline Education (Omitted: high school) & & & \\
\hline Middle School & $\begin{array}{c}-0.240^{* * *} \\
(0.089)\end{array}$ & $\begin{array}{c}-0.234^{* * *} \\
(0.088)\end{array}$ & $\begin{array}{c}-0.233^{* * *} \\
(0.088)\end{array}$ \\
\hline Technical school & $\begin{array}{c}-0.115^{* * *} \\
(0.040)\end{array}$ & $\begin{array}{c}-0.104^{* * *} \\
(0.040)\end{array}$ & $\begin{array}{c}-0.104^{* * *} \\
(0.040)\end{array}$ \\
\hline Two years college/some college & $\begin{array}{l}0.065^{* *} \\
(0.027)\end{array}$ & $\begin{array}{c}0.069 * * * \\
(0.027)\end{array}$ & $\begin{array}{c}0.069^{* * *} \\
(0.027)\end{array}$ \\
\hline Undergraduate & $\begin{array}{c}0.126^{* * *} \\
(0.022)\end{array}$ & $\begin{array}{c}0.122^{* * *} \\
(0.022)\end{array}$ & $\begin{array}{c}0.123^{* * *} \\
(0.022)\end{array}$ \\
\hline Graduate school & $\begin{array}{c}0.278^{* * *} \\
(0.042)\end{array}$ & $\begin{array}{c}0.271^{* * *} \\
(0.042)\end{array}$ & $\begin{array}{c}0.273^{* * *} \\
(0.042)\end{array}$ \\
\hline Marital status (omitted: Single) & & & \\
\hline Married & $\begin{array}{c}0.175^{* * *} \\
(0.024)\end{array}$ & $\begin{array}{c}0.193^{* * *} \\
(0.024)\end{array}$ & $\begin{array}{c}0.194^{* * *} \\
(0.024)\end{array}$ \\
\hline Divorced/Separated/Widowed & $\begin{array}{c}-0.005 \\
(0.043)\end{array}$ & $\begin{array}{c}-0.003 \\
(0.043)\end{array}$ & $\begin{array}{l}-0.001 \\
(0.043)\end{array}$ \\
\hline $\begin{array}{l}\text { Urban (Tokyo. Kanagawa. Nagoya } \\
\text { Osaka. and Fukuoka) } \\
\text { Constant }\end{array}$ & $\begin{array}{c}0.013 \\
(0.017) \\
-0.077 \\
(0.357)\end{array}$ & $\begin{array}{c}0.014 \\
(0.017) \\
0.346 \\
(0.353)\end{array}$ & $\begin{array}{c}0.014 \\
(0.017) \\
-1.203 \\
(0.808)\end{array}$ \\
\hline $\begin{array}{l}\text { Observations } \\
\text { R-squared }\end{array}$ & $\begin{array}{c}10203 \\
0.101\end{array}$ & $\begin{array}{l}10203 \\
0.124\end{array}$ & $\begin{array}{l}10203 \\
0.124\end{array}$ \\
\hline
\end{tabular}


Table 5. Evidence from self-reported reference income. OLS Estimates of Satisfaction with Income

\begin{tabular}{|c|c|c|c|c|c|c|c|}
\hline & $(1)$ & $(2)$ & $(3)$ & $(4)$ & (5) & $(6)$ & (7) \\
\hline Comparison Benchmark & Whole & Family & Neighbours & Friends & Colleagues & Don't compare & Others \\
\hline Dependent Variable & \multicolumn{7}{|c|}{ Satisfaction with Income } \\
\hline Own income & $\begin{array}{c}0.360^{* * *} \\
(0.020)\end{array}$ & $\begin{array}{c}0.242^{* * *} \\
(0.089)\end{array}$ & $\begin{array}{c}0.229 * * * \\
(0.079)\end{array}$ & $\begin{array}{c}0.378^{* * *} \\
(0.031)\end{array}$ & $\begin{array}{c}0.461^{* * *} \\
(0.049)\end{array}$ & $\begin{array}{c}0.331^{* * *} \\
(0.038)\end{array}$ & $\begin{array}{c}0.307^{* * *} \\
(0.116)\end{array}$ \\
\hline Self-reported reference income & $\begin{array}{c}-0.134^{* * *} \\
(0.021)\end{array}$ & $\begin{array}{l}-0.033 \\
(0.090)\end{array}$ & $\begin{array}{l}-0.151 * \\
(0.082)\end{array}$ & $\begin{array}{c}-0.157^{* * *} \\
(0.035)\end{array}$ & $\begin{array}{c}-0.285^{* * *} \\
(0.057)\end{array}$ & $\begin{array}{c}-0.047 \\
(0.038)\end{array}$ & $\begin{array}{c}-0.251^{* *} \\
(0.116)\end{array}$ \\
\hline Observations & 10203 & 483 & 578 & 4279 & 2024 & 2592 & 247 \\
\hline R-squared & 0.101 & 0.113 & 0.115 & 0.091 & 0.092 & 0.095 & 0.240 \\
\hline
\end{tabular}

Note: The regressions in each column include all of the other control variables in Table 4. Column (1) estimate on the whole sample. Columns (2) to (7): each column presents an estimate on the sub-sample of respondents who indicate that they compare to a certain group. 
Table 6 Evidence from internal cell mean reference income. OLS Estimates of Satisfaction with Income

\begin{tabular}{|c|c|c|c|c|c|c|c|}
\hline Cell type & $\begin{array}{c}\text { (1) } \\
\text { age } \\
\text { education }\end{array}$ & $\begin{array}{c}(2) \\
\text { education } \\
\text { job }\end{array}$ & $\begin{array}{c}(3) \\
\text { region }\end{array}$ & $\begin{array}{c}(4) \\
\text { region } \\
\text { age }\end{array}$ & $\begin{array}{c}\text { (5) } \\
\text { age } \\
\text { education } \\
\text { job }\end{array}$ & $\begin{array}{c}\text { (6) } \\
\text { region } \\
\text { education } \\
\text { gender }\end{array}$ & $\begin{array}{c}\text { (7) } \\
\text { age } \\
\text { education } \\
\text { gender } \\
\text { job }\end{array}$ \\
\hline Dependent Variable & \multicolumn{7}{|c|}{ Satisfaction with income } \\
\hline Own income & $\begin{array}{c}0.321^{* * *} \\
(0.030)\end{array}$ & $\begin{array}{c}0.315^{* * *} \\
(0.093)\end{array}$ & $\begin{array}{c}0.318^{* * *} \\
(0.017)\end{array}$ & $\begin{array}{c}0.329 * * * \\
(0.049)\end{array}$ & $\begin{array}{c}0.323^{* * *} \\
(0.051)\end{array}$ & $\begin{array}{c}0.316^{* * *} \\
(0.017)\end{array}$ & $\begin{array}{c}0.321^{* * *} \\
(0.047)\end{array}$ \\
\hline Cell mean reference income & $\begin{array}{c}-0.178 \\
(0.156)\end{array}$ & $\begin{array}{c}0.169 \\
(0.196)\end{array}$ & $\begin{array}{c}0.166^{*} \\
(0.089)\end{array}$ & $\begin{array}{c}-0.290^{* * *} \\
(0.087)\end{array}$ & $\begin{array}{c}-0.037 \\
(0.106)\end{array}$ & $\begin{array}{c}0.122^{*} \\
(0.069)\end{array}$ & $\begin{array}{c}-0.012 \\
(0.092)\end{array}$ \\
\hline Observations & 10203 & 10203 & 10203 & 10203 & 10203 & 10203 & 10203 \\
\hline R-squared & 0.098 & 0.098 & 0.098 & 0.099 & 0.098 & 0.098 & 0.098 \\
\hline
\end{tabular}

Notes: the regressions in each column include all of the other control variables in Table 4.; the standard errors are clustered according to the cell definition at the head of each column. 
Table 7. Evidence from cell mean reference income, based on an external source. OLS Estimates of Satisfaction with Income

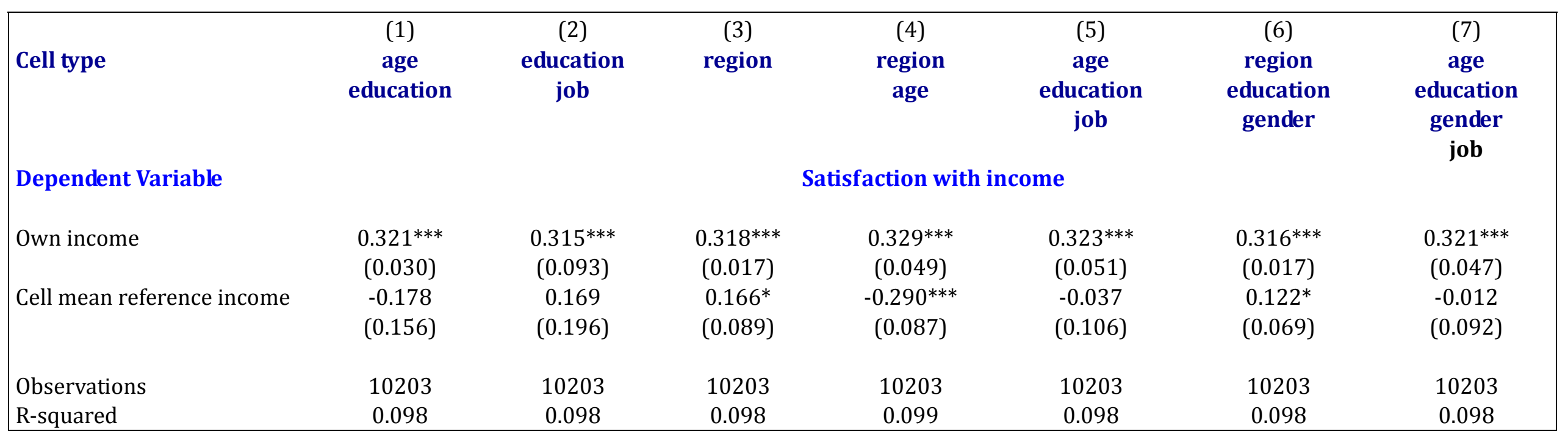

Notes: the regressions in each column include all of the other control variables in Table 4.;

the standard errors are clustered according to the cell definition at the head of each

column. 